\title{
Labour
}

Journal of Canadian Labour Studies

Le Travail

Revue d'Études Ouvrières Canadiennes

\section{Jared Ross Hardesty, Black Lives, Native Lands, White Worlds: A History of Slavery in New England}

\section{Adam McNeil}

Volume 85, printemps 2020

URI : https://id.erudit.org/iderudit/1070923ar

DOI : https://doi.org/10.1353/llt.2020.0022

Aller au sommaire du numéro

Éditeur(s)

Canadian Committee on Labour History

ISSN

0700-3862 (imprimé)

1911-4842 (numérique)

Découvrir la revue

Citer ce compte rendu

McNeil, A. (2020). Compte rendu de [Jared Ross Hardesty, Black Lives, Native Lands, White Worlds: A History of Slavery in New England]. Labour / Le

Travail, 85, 316-318. https://doi.org/10.1353/llt.2020.0022 d'utilisation que vous pouvez consulter en ligne. 
rapid loss of these buildings in the urban renewal era, and the rediscovery and rehabilitation of those that remain during more recent periods of gentrification. He ends by drawing lessons for the current moment in which cities are struggling over housing issues:

While many of the decorated tenements themselves have been rehabilitated, not so the image of those who built and designed them, a fact that has significant consequences for the crisis of housing affordability that again plagues these cities. The image of the builder and designer of low-cost housing as greedy and incompetent, so promoted by the reformers of the late nineteenth and early twentieth century, has remained remarkably persistent. And these biases against multi-family housing remain encoded in zoning, housing maintenance, tax, and building codes they promoted, and in the discourse they encouraged. (228)

At a moment when cities desperately need to rethink how we provide housing, Violette's book is a welcome contribution.

Matt Patterson

University of Calgary

\section{Jared Ross Hardesty, Black Lives, Native Lands, White Worlds: A History of Slavery in New England (Amherst: University of Massachusetts Press 2019)}

IN JARED Ross HARDESTy's follow up text to his 2016 Unfreedom: Slavery and Dependence in Eighteenth-Century Boston, Hardesty returns to the topic of slavery, but with a different interest in trying to connect the entangled histories of slavery, colonization, and emancipation in New England. Black Lives, Native Land, White Worlds is organized around the single theme of connections. Hardesty considers "New England slavery was actually part of a wider world of slavery and colonization in the Americas, and was important for the emergence of American industrial capitalism." (xv) The wider world Hardesty engages still allows him to pay "close attention to the lives of those enslaved in New England and how their experiences related to larger historical processes." (xv) Black Lives, Native Land, White Worlds is the first synthetic treatment of New England slavery since Lorenzo Johnston Greene's The Negro in Colonial New England, and Hardesty's monograph attempts to build on the recent momentum of scholarship on New England slavery and colonization by providing a "short, readable, introduction to New England slavery." (xv) Hardesty has a keen eye on highlighting the lives of and connections built by enslaved New Englanders in the seventeenth and eighteenth centuries.

Key to Hardesty's argument is how New England, though never a slave society, was heavily connected economically to slave societies. Hardesty pushes back against essentialist views about New England's complicity in slave labour practices by connecting how "through interactions with the West Indies, New England found a ready market for commodities and captives, purchased slaves, and learned how to institutionalize slavery." (17) Although never a large destination for trafficked Africans in comparison to the Southern colonies and the West Indies, the slave trade helped finance lucrative economic opportunities for largely, though not exclusively white men. Hardesty uses the example of Mary Bowen, a white woman who in 1793 "purchased a share in a Rhode Island slave ship." (30-31) Slave societies in the American South also were connected to New England slavery. Hardesty connects them by discussing an early eighteenth-century fugitive slave advertisement about "two Carolina Indian Men-Servants." (39) Hardesty asks, "why were Indians from Carolina enslaved in early eighteenth-century $\mathrm{New}$ 
England?" (39) Speculatively, Hardesty provides examples of ways Indigenous people from the Carolinas could have made it to New England during this time. He discusses how the Tuscarora War (1711-1715), was "a part of the 'Spanish phase' of the southeast Indian slave trade, when South Carolina and its allies targeted Spanish missions in what is today southern Georgia and northern Florida." (40) Slavery was an impactful institution in New England, and was, especially initially, enacted upon Indian and African peoples. Although not a slave society, as Hardesty posits, enslavement of Black and Indigenous people still was a violent institution which the enslaved attempted to carve lives out from.

One of the most important interventions and strengths of Black Lives, Native Land, White Worlds is how the monograph centers not only the lives of enslaved people as opposed to centering their enslavers. Hardesty describes the lives of Black New Englanders in vivid detail with accessible prose. Hardesty discusses how for Black New Englanders, public events like Negro Election Day and funerals were important sites of regional Black cultural production. Negro Election Day provided enslaved and free Africans a space to gather "in rural areas to elect a king or, after the American Revolution, a president." (108) Funerals were also important social events for Black New Englanders because they were spaces to communally mourn and honor the dead of a slave labour system that did not care about the lives the institution consumed. Hundreds of people from Black, white, and Indigenous backgrounds attended these funerals. Funerals, unlike Negro Election Day though, did not have much widespread white support. Funerals were feared because they were potential gathering spaces for enslaved people to congregate and, in the hearts and minds of local whites in power, plan insurrections.
In contemporary scholarly discussions, words like "resistance" and "agency" are at times used to describe the above events. Hardesty though, does not label these events as such.

Hardesty cautions his readers against what he dubs the "resistance trap" in slavery studies. He believes historians obstruct the agency of enslaved people because if the limits of enslaved resistance continuously expand, then "every action by an enslaved person or group of enslaved people can be seen as a challenge to their status." (109) Every act by enslaved people certainly cannot and should not be considered resistance. One wonders though, how Black Lives, Native Land, White Worlds would read if the resistance paradigm was foregrounded earlier in the text? When Hardesty discusses the forced breeding of an unnamed woman known as the "queen" by Anglican colonist Samuel Maverick in fellow Anglican colonist John Josselyn's travel account, he details how she screamed and shrieked at Josselyn's door for him to hear her rape account. Not needing to assign whether the enslaved woman's shout was a form of resistance or typifying it as a form of agency, an earlier discussion about Hardesty's interpretation of contemporary scholarly debates about what resistance and agency is and is not would have aided Hardesty's later compelling descriptions about Black lives in early New England.

Today, universities and other institutions are battling over monuments and other public relics to slaveholding and slave trading pasts. Black Lives, Native Land, White Worlds is a valuable text for lay-readers and academics alike to learn about and dissect the interconnected histories of New England slavery and settler colonialism in their communities, to the wider Atlantic World. Beginning Black Lives, Native Land, White Worlds with the Royall House - the only existing 
freestanding slave quarters in the North, located north of Boston in Medford - is important because New England loves relishing in its history; yet, the history of slavery and colonization is as widely discussed, or takes up the physical landscape as much as the American Revolution. From the origins of settler colonialism and Indigenous slavery in the Massachusetts Bay Colony, to the founding of Brown University, to Mum Bett and Quok Walker's landmark Massachusetts Supreme Court cases, Hardesty shows how Black and Indigenous New Englanders at every turn of its history, fought against their subjection. In doing so, despite their subjected statuses, they still created lives for themselves. Black Lives, Native Land, White Worlds is a phenomenal way to begin learning more about them.

AdAM MCNEIL

Rutgers University

\section{Emily L. Thuma, All Our Trials: Prisons, Policing, and the Feminist Fight to End Violence (Champagne: University of Illinois Press 2019)}

THE IMAGE OF PRISONS as judicious machines of enclosure, and the conception of impartial justice this image serves, are shattered by the activism documented in Emily L. Thuma's All Our Trials: Prisons, Policing, and the Feminist Fight to End Violence. Looking at archives in the United States, Thuma follows the trajectories of feminist movements in the 1970s and the 1980s, whose fringes fostered an abolitionist and anti-carceral mode of feminism. These movements were abolitionist and anti-carceral in that these women sought the dissolution of and alternatives to prisons. For example, rallying behind women prosecuted and incarcerated for killing their assaulters
- cases in which self-defence was argued - these women attended to the failure of the state to protect women from sexual violence. In doing so, the "liberal legal imaginary" (80) in which victims are clearly differentiated from criminals was upended. But these fringes also went further, in that they also advocated for compassionate and communal interventions for those who raped or committed sexual assault, instead of participating in the violence of the state. The state was identified as the ultimate assaulter - particularly a state engaged in advancing a white, male, and capital-controlling class - and abetting that class violence by seeking justice through the state's criminal legal system guaranteed the problem in perpetuity.

Critically, Thuma tells us, this cry for abolition was informed by looking inward and to others as women, particularly as Black, Indigenous, Latina, and/or incarcerated women, and drawing from their lived experience. By experiencing the prison and policing as inseparable from projects of white supremacy and the alienation and exploitation of labourers, these women diagnosed incarceration as a political practice continuous with colonial and capitalist social formations. Criminality was not the disease of the body, to be extracted through enclosure; instead, these women saw beyond this simulacrum and dislocated carceral frames to bring into focus the manifold violence of the state. Incarceration was constitutive of the criminal and the inmate, alongside social formations that impoverished, marginalized, and harmed people of colour, Indigenous peoples, immigrants, queer and trans peoples, and workers. All prisoners were in fact political prisoners to these women, in that their race, gender, and bodies transgressed preferred political arrangements and institutions thought of as conducive 